\title{
Single- and multiple-dose pharmacokinetics, pharmacodynamics, and safety of apixaban in healthy Chinese subjects [Corrigendum]
}

\author{
Cui Y, Song Y, Wang J, et al. Clinical Pharmacology: \\ Advances and Applications. 2013;5(1):177-184.
}

Note that on page 182, Figure 3 should be corrected as follows, with the line for mean anti-Xa activity extended through to 72 hours post dose on Day 9, and the Day 1 plasma apixaban concentration-time profile rendering error bars and symbols more visually apparent.
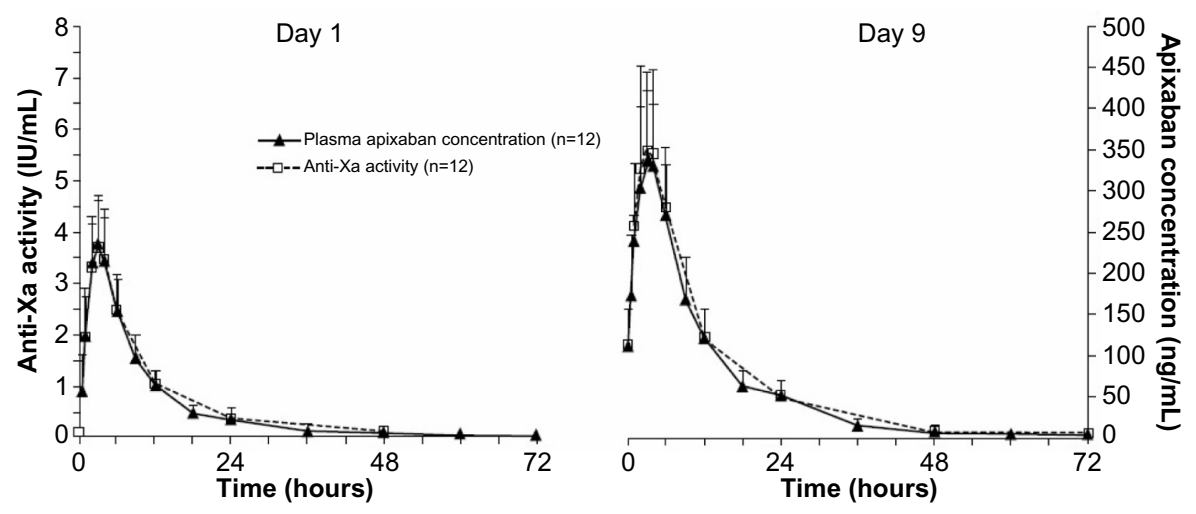

Figure 3 Mean anti-Xa activity and plasma apixaban concentration versus time following single-dose administration (day I) and at steady state (day 9). Error bars show + I standard deviation from the mean.

\section{Publish your work in this journal}

Clinical Pharmacology: Advances and Applications is an international, peer-reviewed, open access journal publishing original research, reports, reviews and commentaries on all areas of drug experience in humans. The manuscript management system is completely online and includes a very quick and fair peer-review system, which is all easy to use.
Visit http://www.dovepress.com/testimonials.php to read real quotes from published authors. 